\title{
Can Flaxseed Help Satisfy Appetite in Women Subjected to Bariatric Surgery?
}

\section{Gigliane Cosendey Menegati ${ }^{\mathrm{a}, *}$, Larissa Cohen ${ }^{\mathrm{a}}$, Fernanda Cristina Carvalho de Mattos ${ }^{\mathrm{b}}$, Mariana Paes de Miranda ${ }^{a}$ y Eliane Lopes Rosado ${ }^{a}$}

\author{
a Departamento de Nutrição Dietética, Instituto de Nutrição Josué de Castro, Universidade Federal do Rio de Janeiro, \\ Rio de Janeiro, Brasil \\ ${ }^{\mathrm{b}}$ Departamento de Clínica Médica, Serviço de Nutrologia, Hospital Universitário Clementino Fraga Filho, Universidade \\ Federal do Rio de Janeiro, Rio de Janeiro, Brasil
}

Recibido el 26 de julio de 2011; aceptado el 23 de enero de 2012

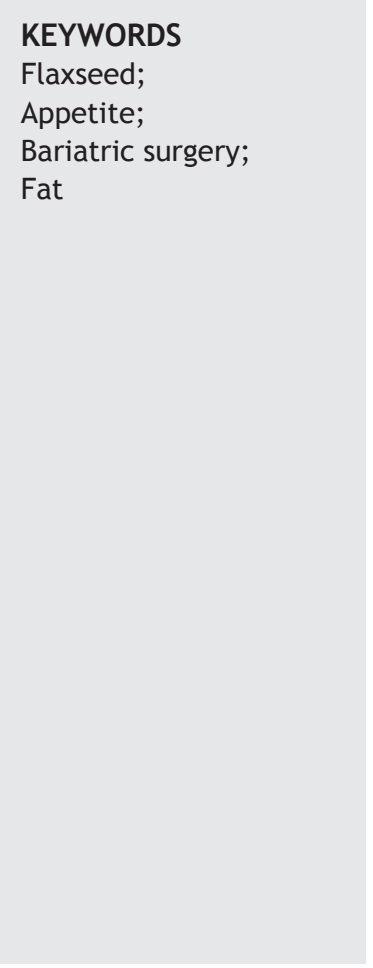

\begin{abstract}
Background: Bariatric surgery is considered the most effective immediate weight loss method for the morbidly obese, despite widely reported weight regain after a few years. Appetite, satiety and satiation control are essential to maintaining a long-term result post-surgery. Dietary fatty acids composition may be implicated in the satiety. As flaxseed is a food high in linolenic acid, we aimed to verify the influence of flaxseed fat on appetite and satiety of women after bariatric surgery.

Material and methods: Six women who underwent bariatric surgery at least 2 years before participated in a single-blind crossover trial that compared the effect of two isocaloric meals on satiety, one containing whole golden flaxseed (high in polyunsaturated fatty acids and fiber) (G1) and another withdefatted flaxseed (high in fiber) (G2), with one week of washout period. This variable was estimated by visual analogue scales in both meals at baseline (T0), immediately after ingestion (T1) and 60, 120, and 180 minutes after the meal (T60, T120 and T180). Fasting anthropometric, body composition, laboratory tests (glucose and lipids) and dietary variables, were evaluated while fasting. Results: The volunteers were obese and had excess central adiposity, even after two years of surgery and still showed habitual fibre intake below recommended levels. G1 had reduced hunger after 180 minutes compared to $G 2(P=.046)$. Other parameters related to appetite and satiety did not differ between groups.

Conclusions: Less hunger was observed after 180 minutes in whole golden flaxseed meal compared with the defatted flaxseed meal, indicating that the whole golden flaxseed meal, possibly, supports obesity treatment in the long-term after bariatric surgery by controlling appetite and satiety sensations.

(C) 2012 Asociación Española de Dietistas-Nutricionistas. Published by Elsevier España, S.L. All rights reserved.
\end{abstract}

\footnotetext{
*Autor para correspondencia.
}

Correo electrónico: guianenut@ig.com.br (G. Cosendey Menegati). 


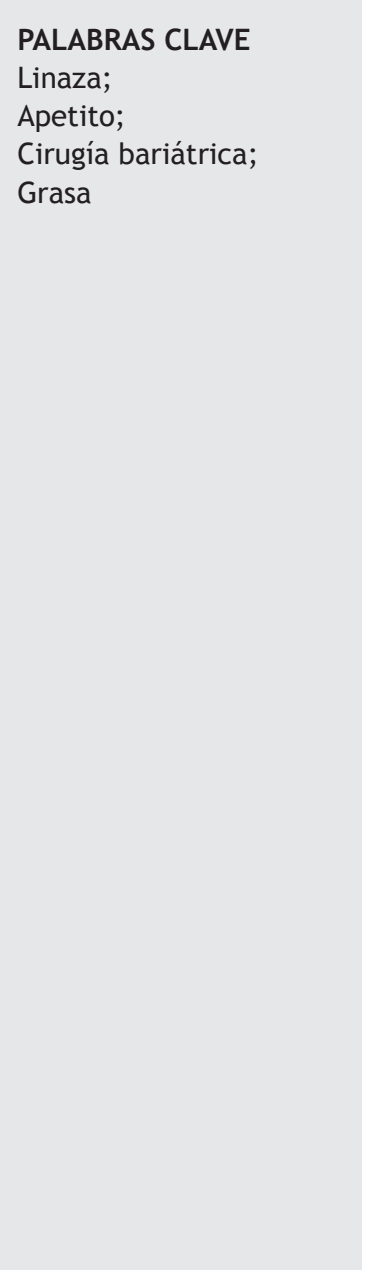

\author{
¿La linaza puede incrementar la saciedad de las mujeres sometidas a cirugía \\ bariátrica?
}

\section{Resumen}

Antecedentes: Se considera que la cirugía bariátrica es el método inmediato más eficaz para la pérdida de peso en la obesidad mórbida a pesar de observarse, en algunos casos, la recuperación del peso corporal después de algunos años. El control del apetito, la saciedad y la satisfacción son esenciales para que los resultados se mantengan a largo plazo después de la cirugía. La composición de ácidos grasos de la dieta podría ser un factor implicado en la regulación de la saciedad. Debido a que la linaza es un alimento con alto contenido en ácido linolénico, el objetivo del presente estudio es verificar la influencia de la grasa de la linaza en el apetito y la saciedad de las mujeres después de la cirugía bariátrica.

Material y métodos: Seis mujeres que se habían sometido a cirugía bariátrica al menos 2 años antes participaron en un ensayo cruzado a simple ciego que comparó el efecto en la saciedad de dos comidas isocalóricas que contienen linaza dorada integral (rica en ácidos grasos poliinsaturados y fibra) (G1) y linaza desgrasada (rica solamente en fibra) (G2), con 1 semana de aclaramiento. Esta variable se estimó mediante escala analógica visual en las dos comidas, en el periodo basal (T0), inmediatamente después de la ingestión (T1) y 60, 120 y 180 min después (T60, T120 y T180). Además, se evaluó la antropometría, la composición corporal y variables de laboratorio (glucosa y los lípidos) y dietéticas, en ayunas.

Resultados: Los voluntarios eran obesos y tenían exceso de adiposidad central, incluso 2 años después de la cirugía, y aún mostraban ingesta habitual de fibra por debajo de la cantidad recomendada. G1 presentó reducción del hambre después de 180 min en comparación con $\mathrm{G} 2(\mathrm{p}=0,046)$. Otros parámetros relacionados con el apetito y la saciedad no difirieron entre los grupos.

Conclusiones: Se observó menos hambre 180 min después de ingerir linaza dorada integral en comparación con la linaza desgrasada, lo que indica que la linaza dorada integral podría estar indicada en el tratamiento de la obesidad a largo plazo tras cirugía bariátrica, debido al control de las sensaciones de apetito y saciedad.

(c) 2012 Asociación Española de Dietistas-Nutricionistas. Publicado por Elsevier España, S.L. Todos los derechos reservados.

\section{Introduction}

Obesity is a multifactorial disease characterized by excessive body fat that predisposes individuals to diseases such as dyslipidaemia, cardiovascular disease, hypertension, type 2 diabetes and some types of cancer ${ }^{1}$.

According to World Health Organization, in 2005, approximately 1.6 billion adults were overweight and 400 million were obese. It is estimated that by 2015 there will be approximately 2.3 billion overweight, and more than 700 million obese adults ${ }^{2}$. There is a peak prevalence of obesity at around 50 to 60 years old in developed countries and in developing countries it affects people at around 40 to 50 years old ${ }^{3}$.

Obese individuals who cannot lose weight through lifestyle changes or drug treatment are candidates for bariatric surgery. This intervention is indicated for patients with a body mass index (BMI) $\geq 40$ or $\mathrm{BMI} \geq 35$ in the presence of high-risk comorbidity, such as sleep apnoea or uncontrolled type 2 diabetes, and patients with a BMI between 35 and 40 as their obesity will result in physical problems compromising their mobility and social life ${ }^{4}$.
In addition to weight loss after surgery, hyperlipidaemia, hypertension and type 2 diabetes are improved or eliminated ${ }^{5}$. Surgery completely changes the diet profile and its success arises not only from weight loss, but also the associated nutritional education, in order to avoid postsurgical problems such as nutritional deficiency ${ }^{6}$. However, after the adaptation phase, food intake can achieve similar patterns to the habitual intake in the pre-operative phase. There are reports in the literature of weight regain after gastric bypass ${ }^{7}$. Therefore, appetite, satiety and satiation control would be a maintenance long-term results strategy for the post surgery ${ }^{8}$.

Satiety refers to cessation of hunger and reduces postprandial food intake until the next meal ${ }^{9}$. Satiation prevents over-eating during individual meals ${ }^{8}$, thereby avoiding deleterious consequences from incomplete digestion, as well as excessive disturbances in circulating levels of glucose, for instance. Satiety arises through various mechanisms stimulated by food presence in the gastrointestinal tract, with gastric distension and release of bowel peptides 9 . High fibre and protein foods increase satiety, thus reducing energy food intake ${ }^{10}$. Dietary fatty acids composition may be associated with satiety. 
Polyunsaturated fatty acids (PUFA) have a greater influence on satiety than monounsaturated (MUFA) and saturated fatty acids (SFA) ${ }^{11}$.

Fat characteristics play an important role in controlling appetite and body weight. In this sense flaxseed stands out as a food high in alpha-linolenic acid (approximately $57 \%$ of all flaxseed fatty acids), with significant preventive function in cardiovascular diseases. It is also an essential source of soluble and insoluble fibres. Soluble fibre acts by reducing blood glucose and lipids, while the insoluble fraction improves bowel function, preventing constipation ${ }^{12}$.

Being a high PUFA and fibre food, flaxseed may control appetite, playing a role in weight loss and weight maintenance processes in patients after bariatric surgery. Moreover, it is important to know the fat composition in the usual diet of individuals, since the level of fat saturation may influence appetite ${ }^{11}$.

Thus, this study aims to verify whether the presence or absence of fat in flaxseed composition influences the appetite and satiety sensations. Furthermore, another purpose is to associate knowledge of habitual macronutrients dietary intake and lipid profile with appetite-related variables after flaxseed intake.

\section{Material and methods}

\section{Subjects}

Volunteers were recruited and selected in the University Hospital Clementino Fraga Filho (HUCFF), in Rio de Janeiro (Brazil). We selected adult women treated at the HUCFF, who had undergone bariatric surgery ( $\mathrm{Y}$ en Roux) at least two years before.

Exclusion criteria were as follows: malignant tumours, infectious diseases and visual disturbances that prevented completing the visual analogue scale (VAS). The recruitment was conducted by telephone, after collecting data from the medical records of the Department of Physical Medicine and Rehabilitation from the Federal University of Rio de Janeiro.

The Ethics Committee of the HUCFF approved the protocol and all patients provided written informed consent.

\section{Procedure}

This was a single-blind randomized crossover trial. At the initial visit volunteers had to complete a general data questionnaire and were guided on how to complete three day food record (two weekdays and one weekend day) ${ }^{13}$. Food records were analysed by DietPro version 5 software ${ }^{14}$.

Visits were scheduled with a minimum interval of one week since the first one, in which the trial was held, and volunteers were told to maintain their usual physical activity.

On the test day, after 12 hours overnight fasting, anthropometric, body composition and laboratory variables were measured $(7: 00 \mathrm{am})$. Volunteers received randomized test meals (muffins containing whole golden flaxseed [G1] or defatted flaxseed [G2]) (7:30 am) and were consumed within a 30-minute period. A VAS was used to evaluate appetite and satiety, immediately before (TO) and after (T1) test meal consumption, and 60, 120, 180 minutes after meal, indicated as T60, T120 and T180. After a wash-out period of one week, volunteers returned for second trial. Satiety assessment was performed by comparing the T1 T180, with 3 hours interval between meals.

Volunteers rated their appetite sensations, satiation, consumption of sweets, snacks, appetizers and fatty foods using a VAS validated by Flint et $\mathrm{al}^{15}$. Subjective feelings were recorded by placing a vertical line across $100 \mathrm{~mm}$ scales to indicate the intensity of what was being assessed. Quantification was made by measuring the distance from the left side to the volunteer's mark with a millimetre ruler.

Test meals were prepared by researchers using the flaxseed supplied by the Cisbra Group ${ }^{\circledR}$ Company. Two types of muffins containing whole golden flaxseed and defatted flaxseed were prepared. Both types of muffins had similar percentages of macronutrient and energy values. Other ingredients were identical for both groups, and both were given sugar free fruit juice to accompany the muffin. The amount of flaxseed in the muffins composition was $10 \mathrm{~g}$ per unit, however, the test meal was calculated individually, according to the resting energy expenditure (REE) of each volunteer using the WHO formula $(1985)^{16}$, corresponding $1 / 6$ of the REE, comprising $15-20 \%$ of REE in the form of muffin plus juice, equivalent to a breakfast energy value. The whole golden flaxseed contained $0.33 \mathrm{~g}$ of SFA, $0.6 \mathrm{~g}$ of MUFA and $2.26 \mathrm{~g}$ of PUFA ( $\mathrm{n}-3: 1.86 \mathrm{~g}$ and $\mathrm{n}-6: 0.4 \mathrm{~g}$ ), and the defatted flaxseed had $0.13 \mathrm{~g}$ of SFA, $0.4 \mathrm{~g}$ of MUFA and $1.2 \mathrm{~g}$ of PUFA ( $\mathrm{n}-3: 1.0 \mathrm{~g}$ and $\mathrm{n}-6: 0.2 \mathrm{~g})$.

Body weight was measured by the nutritionist using a Welmy ${ }^{\circledR}$ digital scale with $300 \mathrm{~kg}$ capacity, with bare feet and wearing light clothing. Height was measured in centimetres using an anthropometric ruler balance with the subjects standing erect with their backs to the scale with heels together ${ }^{17}$.

The waist circumference (WC) measurement, in centimetres, and was performed using a Sanny ${ }^{\circledR}$ non-elastic anthropometric tape of $2.0 \mathrm{~m}$ long applied at the midpoint between the lower rib margin and the iliac crest. Three measurements were made and the average taken. The WC measurement standardization was carried out according to WHO $(1988)^{18}$.

Body composition was measured by bioelectrical impedance (Biodynamics 450 model), based upon the conduction of an applied electrical current into the body enabling the total body water (TBW) and lean body mass (LBM) values to be obtained. The difference between the total body mass and fat-free mass (FFM) gives the total body fat (TBF), using the two-compartment model. For this assessment, volunteers were instructed not to perform physical activity within the $24 \mathrm{~h}$ prior to examination, not to drink $1 \mathrm{~h}$ before the test and to empty their bladder, as well as being in the fasting state ${ }^{19}$.

Lipid profile and blood glucose were assessed at HUCFF by appropriately trained staff. Serum glucose, total cholesterol $(\mathrm{mg} / \mathrm{dL})$, high density lipoprotein (HDL-chol) $(\mathrm{mg} / \mathrm{dL})$ and triglycerides $(\mathrm{TG})(\mathrm{mg} / \mathrm{dL})$ were measured by an enzymatic colorimetric method using CELM ${ }^{\circledR}$ and

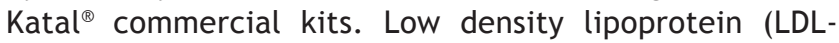


chol) (mg/dL) was calculated according to Friedewald formula (20).

Data were analysed as mean and standard deviation. The normality of the data distribution was verified by Kolmogorov-Smirnov test. Comparisons of energy and nutrients intake between groups were performed using the Student- $t$ test for independent samples. Appetite related variables in the same group were analysed by Mann-Whitney test. Wilcoxon test was used to assess the hunger between groups and the effect size between groups, and baseline and postprandial time points were calculated by means of Cohen's $d$ test. A significance of $P<.05$ was considered. SPSS version 16 software was used for statistical analysis.

\section{Results}

Of the 21 adult subjects initially screened, thirteen had difficulty in attending the tests and two volunteers dropped out for personal reasons after the first trial. The study was conducted with six adult women after bariatric surgery for obesity treatment at a minimum of 2 years (average time 3.7 years). Volunteers participated in both clinical trials and receive muffins containing whole golden flaxseed and defatted flaxseed in different weeks.

The anthropometric and laboratory characteristics of the volunteers are shown in Table 1. Women were classified as class I obese and overweight ${ }^{21}$ and had excess of central adiposity and total body fat. All patients were normoglycaemic and had normal lipid parameters.

Habitual dietary intake assessed by a three-day food record was normal in energy, carbohydrates and fats (Table $2)$. Protein intake was above the recommendation $(0.8$ $1.0 \mathrm{~g} / \mathrm{kg} /$ day), with an average intake of $0.85 \mathrm{~g}$ protein per $\mathrm{kg}$ of current weight. PUFA, MUFA and SFA intake were also in accordance with the recommendations. On the other hand, the fibre was lower than the recommended fibre intake ${ }^{22}$.

The energy and nutrients intake of test meals are shown in Table 3. There were significant differences for PUFA $(P=.018)$. It is worth mentioning that the most abundant fatty acids in flaxseed are PUFA, with a higher proportion of n-3 PUFA. Whereas the defatted flaxseed muffin has a lower amount of PUFA $(1.2 \mathrm{~g})$ compared with whole golden flaxseed meal $(2.26 \mathrm{~g})$, the level of linolenic fatty acid is also lower in the defatted flaxseed meal.

No difference was observed $(P=.05)$ between groups for the variables of, hunger, satisfaction, and need to eat fatty foods 180 minutes after muffins ingestion. Gastric fullness and satiation variables also showed no differences immediately after ingestion (Table 4$)$. However, there was hunger reduction for 180 minutes $(P=.05)$ in $\mathrm{G} 1$, which did not occur in G2 (Table 5).

According to Cohen's d test, the effect size for the "hunger" variable was small at TO, verified by the absence of a difference between groups (Tables 4 and 5), and at T180 the effect size was medium. Applying the test in each group separately (T0 vs T180), the effect size remained medium, however, in $\mathrm{G} 1$ the percentile was situated between 66-69 and in $\mathrm{G} 2$ it was between 62-66, explaining the significant difference in $\mathrm{G} 1$ (Table 5).
Table 1 Anthropometric and laboratory variables $($ mean $\pm S D)$ of women

\begin{tabular}{lc}
\hline Variables & Mean \pm SD \\
\hline BMI & $33.07 \pm 4.40$ \\
WC $(\mathrm{cm})$ & $95.33 \pm 9.42$ \\
TBW $(\mathrm{l})$ & $36.96 \pm 6.26$ \\
TBF $(\%)$ & $38.90 \pm 6.80$ \\
LBM $(\mathrm{kg})$ & $49.76 \pm 8.04$ \\
Total cholesterol $(\mathrm{mg} / \mathrm{dL})$ & $154.00 \pm 22.00$ \\
LDL-chol $(\mathrm{mg} / \mathrm{dL})$ & $78.20 \pm 17.41$ \\
HDL-chol $(\mathrm{mg} / \mathrm{dL})$ & $62.33 \pm 8.75$ \\
Triglycerides $(\mathrm{mg} / \mathrm{dL})$ & $66.67 \pm 12.22$ \\
Fasting glucose $(\mathrm{mg} / \mathrm{dL})$ & $70.17 \pm 5.91$ \\
\hline
\end{tabular}

BMI: body mass index; LBM: lean body mass; TBF: total body fat; TBW: total body water; WC: waist circumference.

Table 2 Volunteers habitual dietary intake $($ mean \pm SD)

\begin{tabular}{lc}
\hline Variables & Mean \pm SD \\
\hline Total energy intake $(\mathrm{kcal})$ & $1264.10 \pm 231.49$ \\
Carbohydrate $(\% \mathrm{TEI})$ & $50.89 \pm 12.01$ \\
Protein $(\% \mathrm{TEI})$ & $20.16 \pm 7.62$ \\
Fat $(\% \mathrm{TEI})$ & $28.97 \pm 8.93$ \\
PUFA $(\% \mathrm{TEI})$ & $4.34 \pm 1.59$ \\
MUFA (\%TEI) & $6.16 \pm 2.36$ \\
SFA (\%TEI) & $6.14 \pm 2.27$ \\
Fibre $(\mathrm{g})$ & $9.56 \pm 1.87$ \\
Triglycerides $(\mathrm{mg} / \mathrm{dL})$ & $66.67 \pm 12.22$ \\
Fasting glucose $(\mathrm{mg} / \mathrm{dL})$ & $70.17 \pm 5.91$ \\
\hline
\end{tabular}

MUFA: monounsaturated fatty acid; PUFA: polyunsaturated fatty acid; SFA: saturated fatty acid; TEl: total energy intake.

Table 3 Energy and nutrient intake of the two test meals (mean \pm SD

\begin{tabular}{llll}
\hline Variables & G1 & G2 & $P$-value \\
\hline $\begin{array}{l}\text { Total energy intake } \\
\text { (kcal) }\end{array}$ & $240.48 \pm 74.51$ & $253.35 \pm 78.50$ & .777 \\
Protein (\% TEI) & $11.95 \pm 3.70$ & $13.00 \pm 4.03$ & .465 \\
Carbohydrate & $64.70 \pm 20.04$ & $69.60 \pm 21.56$ & .502 \\
(\% TEI) & & & \\
Fat (\% TEI) & $23.32 \pm 7.23$ & $17.40 \pm 5.40$ & .215 \\
SFA (\% TEI) & $2.93 \pm 0.91$ & $2.36 \pm 0.73$ & .391 \\
MUFA (\% TEI) & $4.68 \pm 1.45$ & $4.26 \pm 1.32$ & .824 \\
PUFA (\% TEI) & $14.34 \pm 4.45$ & $7.69 \pm 2.39$ & .018 \\
Fibre (g) & $4.62 \pm 1.43$ & $6.25 \pm 1.94$ & .130 \\
\hline
\end{tabular}

MUFA: monounsaturated fatty acid; PUFA: polyunsaturated fatty acid; SFA: saturated fatty acid; TEl: total energy intake. $P$-value differences between test groups were tested with $\mathrm{t}$ test (independent samples) at $5 \%$ probability. 
Table 4 Appetite-related variables of the two test meals $($ mean \pm SD)

\begin{tabular}{lrlc}
\hline Variables & \multicolumn{1}{l}{ G1 } & G2 & $P$-value \\
\hline Hunger T180' & $3.08 \pm 2.35$ & $4.65 \pm 1.97$ & .199 \\
Satisfaction T1' & $9.98 \pm 0.04$ & $9.95 \pm 0.11$ & .902 \\
Satisfaction T180' & $4.70 \pm 1.61$ & $3.73 \pm 1.85$ & .520 \\
Gastric fullness T1' & $9.98 \pm 0.04$ & $9.85 \pm 0.29$ & .461 \\
Fat necessity T180' & $9.25 \pm 1.07$ & $9.23 \pm 1.12$ & 1 \\
MUFA (\% TEI) & $4.68 \pm 1.45$ & $4.26 \pm 1.32$ & .824 \\
PUFA (\% TEI) & $14.34 \pm 4.45$ & $7.69 \pm 2.39$ & .018 \\
Fibre (g) & $4.62 \pm 1.43$ & $6.25 \pm 1.94$ & .130 \\
\hline
\end{tabular}

$P$-value, differences between groups were tested using nonparametric Mann-Whitney test at 5\% probability.

Table 5 Hunger feeling (mean $\pm S D)$, before and after test meal, in the groups

\begin{tabular}{lccll}
\hline Variables & G1 & G2 & $\begin{array}{l}\text { Cohen's d } \\
\text { test }\end{array}$ & $\begin{array}{l}\text { Effect } \\
\text { size }\end{array}$ \\
\hline Hunger T0' & $5.53 \pm 1.93$ & $6.46 \pm 3.01$ & 0.37 & 0.18 \\
Hunger T180' & $3.08 \pm 2.57$ & $4.65 \pm 2.17$ & 0.65 & 0.31 \\
$P$-value & .046 & .463 & & \\
Cohen's d test & 1.08 & 0.69 & & \\
Effect size & 0.47 & 0.33 & & \\
\hline
\end{tabular}

$P$-value, difference between groups were tested using Wilcoxon test at $5 \%$ probability.

\section{Discussion}

Bariatric surgery is considered the most effective immediate weight loss method for the morbidly obese. However, it does not mean a guarantee of continued weight loss over time, since changes in eating habits do not occur necessarily due to patients undergoing surgery, resulting in inadequate weight loss or lost body weight recovery ${ }^{7}$.

The volunteers in this study were class I obese and overweight ${ }^{21}$ and had bariatric surgery performed at a mean time of 3.7 years. In addition, they had marked central adiposity, which features a very high risk for metabolic complications associated with obesity ${ }^{23}$.

Magro et al. conducted a prospective study in which they studied body weight recovery in 782 patients who had undergone bariatric surgery and found that $50 \%$ recovered the lost weight 24 months after surgery ${ }^{24}$. Dapri et $\mathrm{al}^{25}$ also reported the recovery of long-term weight in patients after bariatric surgery, due to the increase in dietary intake, since this time period the restriction is not very acute and meal volume is higher than in the post-operative period. Body weight recovery two years after surgery was also reported by Faria et $\mathrm{al}^{26}$, where an average recovery of $8 \mathrm{~kg}$ was observed, and nutritional counselling was offered to these individuals in order to achieve weight loss again. It reinforces the fact that bariatric surgery does not lead to an obesity cure, thus nutritional counselling is important the not only immediately after surgery, when food intake is restricted and there is increased susceptibility to severe nutritional deficiencies, but also in long-term to minimize the recovery of body weight loss, which could lead to the same weight prior to surgery.

Despite the class I obesity observed in volunteers, they had normal fasting serum glucose and lipids ${ }^{23}$. Ribeiro et $\mathrm{a}^{27}$ followed up 80 women after bariatric surgery and found a significant blood glucose improvement after a year of surgery. Silva and Sanches ${ }^{28}$ studied the lipid profile of obese patients before and after bariatric surgery. They showed a significant reduction in serum total cholesterol, LDL-chol and triglycerides with an increased HDL-chol, one year after surgery, but a significant correlation between the weight loss and improved lipid profile was not found.

The habitual dietary intake of the volunteers indicated that both macronutrients and lipid profile were similar to the nutritional recommendations. Protein intake per kilogram of body weight per day was adequate and fibre intake was below the recommendation $(20 \mathrm{~g}$ to $30 \mathrm{~g}$ per day $)^{22}$. Deficient fibre intake is one of the causes that can stop weight loss due to the fact that fibre leads to an increase in satiety ${ }^{29}$.

Hunger, fullness, desire to eat something greasy, and satiation did not differ between groups. However, when analysing hunger sensation at different times for each test meal (T0 and T180), it was found that G2 did not differ for hunger, resulting in lower meal-induced satiety. This event did not occur in $\mathrm{G} 1$, whereas there was reduction of hunger during the same period, reflecting increased satiety induced by whole golden flaxseed. This difference could be due to the higher PUFA content in the whole golden flaxseed meal, emphasising the influence of this nutrient in satiety. It should be mentioned that flaxseed is rich in linolenic acid ${ }^{12}$. Fibre in test meals could also lead to satiety, but fibre amount did not differ between groups.

High fat foods can lead to post-prandial satiety, being able to reduce the gastric emptying and decreasing appetite and energetic intake ${ }^{30}$. Essah et $\mathrm{al}^{31}$ conducted a study with obese subjects, comparing a high carbohydrate and low fat diet with a high fat and low carbohydrate diet and observed that individuals who ingested more fat had higher secretion of peptide YY, which inhibits energy intake. It showed that total fat intake can help to control appetite and satiety, but should be planned with caution, as it is high energy-nutrient dense. In the present study, total fat content did not differ between groups, only PUFA content.

Sales et al $^{32}$ evaluated different types of oils (olive oil, safflower and peanut) effect on food intake in normal weight normolipidaemic individuals and showed no significant difference in satiety and satiation among different groups or over time. Another study on overweight men found no difference in appetite, both baseline and postprandial, after PUFA, MUFA and trans-fatty acids intake ${ }^{33}$. However, Lawton et al ${ }^{11}$ offered patients high oleic and linoleic fatty acid meals and the authors suggested a greater influence on satiety from linoleic fatty acids. Smeets and Westerterp-Plantenga also reported a significant role of linoleic acid in appetite control ${ }^{34}$.

Parra et $\mathrm{al}^{35}$ conducted a randomised study in which volunteers followed a weight control diet and received n-3 
PUFAs (linolenic fatty acid) by eating lean or fat fish or by fish oil capsules, and observed that those who ingested more n-3 PUFA felt greater gastric fullness compared with those who ingested a smaller amount of this nutrient, two hours post-prandial.

We suggest carrying out long-term studies to assess dietary intake and associate it with anthropometric variables and hormones related to appetite sensations. Research on these study characteristics is not easy to conduct, since recruitment of patients two years after bariatric is difficult due to their distance from the medical team.

\section{Conclusions}

Our study results showed there was less hunger after 180 minutes after a whole golden flaxseed meal compared with a defatted flaxseed meal, indicating that the whole golden flaxseed meal, possibly, supports obesity treatment in the long-term after bariatric surgery by controlling appetite and satiety sensations. The study showed that volunteers were obese and had excess central adiposity even after two years of surgery and still showed habitual fibre intake below recommended levels, emphasising the importance of nutritional counselling in the long-term.

\section{Acknowledgment}

We are thankful to the Cisbra Group for providing the flaxseed used in the study and Dr. Maria de Fátima Carvalho Pereira, Chief of the Biochemistry in the Department of Pathology, University Hospital Clementino Fraga Filho for providing blood analysis.

\section{Conflict of interest}

The authors declare no conflicts of interests.

\section{References}

1. Faria AM, Mancini MC, De Melo ME, Cercato C, Halpern A. Recent progress and novel perspectives on obesity pharmacotherapy. Arq Bras Endocrinol Metabol. 2010;54:516-29.

2. World Health Organization. Fact sheet: obesity and overweight [citado 26 May 2009]. Disponible en: http://www.who.int/ mediacentre/factsheets/fs311/en/print.html

3. Low S, Chin MC, Deurenberg-Yap M. Review on Epidemic of Obesity. Ann Acad Med Singapore. 2009;38:57-65.

4. AACE/TOS/ASMBS Guidelines. American Association of Clinical Endocrinologists, The Obesity Society, and American Society for Metabolic \& Bariatric Surgery Medical Guidelines for Clinical Practice for the Perioperative Nutritional, Metabolic, and Nonsurgical Support of the Bariatric Surgery Patient. Surg Obes Relat Dis. 2008;4:S109-84.

5. Maggard MA, Shugarman IR, Suttorp M, Maglione M, Sugerman $\mathrm{HJ}$, Livingston EH, et al. Meta-analysis: surgical treatment of obesity. Ann Intern Med. 2005;142:547-59.

6. Moizé VL, Pi-Sunyer X, Mochari H, Vidal J. Nutritional pyramid for post-gastric bypass patients. Obes Surg. 2010;20:1133-41.
7. Dapri G, Cadière GB, Himpens J. Laparoscopic placement of non-adjustable silicone ring for weight regain after Roux-en- $Y$ gastric bypass. Obes Surg. 2009;19:650-4.

8. Scopinaro N, Gianetta E, Friedman D. Biliopancreatic diversion for obesity. Probl Gen Surg. 1992;9:362-79.

9. Blundell J, De Graaf C, Hulshof T, Jebb S, Livingstone B, Lluch A, et al. Appetite control: methodological aspects of the evaluation of foods. Obes Rev. 2010;11:251-70.

9b. Blundell JE, Halford JC. Regulation of nutrient supply: the brain and appetite control. Proc Nutr Soc. 1994;53: 407-18.

10. Lee YP, Mori TA, Sipsas S, Barden A, Puddey IB, Burke V, et al. Lupin-enriched bread increases satiety and reduces energy intake ocutely. Am J Clin Nutr. 2006;84:975-80.

11. Lawton CL, Delargy HJ, Brockman J, Smith FC, Blundell JE. The degree of saturation of fatty acids influences post-ingestive satiety. Br J Nutr. 2000;38:477-82.

12. Dodin S, Lemay A, Jacques H, Légaré F, Foreste JC, Mâsse B. The effects of flaxssed dietary supplement on lipid profile, bone mineral density, and symptoms in menopausal women: a randomized, doubled-blind, wheat germ placebo-controlled clinical trial. J Clin Endocrinol Metab. 2005;90:1390-7.

13. Stuff JE, Garza C, Smith EO, Nichols BL, Montandon CM. A comparison of dietary methods in nutritional studies. Am J Clin Nutr. 1983;37:300-6.

14. DIETPRO $5 i$ tecnologia para nutrição. Versão 5i. Viçosa: A.S. Sistemas, 2008. 1 CD-ROM.

15. Flint A, Raben A, Blundell JE, Astrup A. Reproducibility, power and validity of visual analogue scales in assessment of appetite sensations in single test meal studies. Int J Obes. 2000;24: 38-48.

16. FAO (Food and Agriculture Organization) / WHO (World Health Organization) / UNU (United Nations University). Energy and protein requirements. WHO Technical Report Series, n. 724. Geneva: WHO; 1985.

17. World Health Organization (WHO). Physical status: the use and interpretation of anthropometry. Report of a WHO Expert Committee. Technical Report Series, n. 854. Geneva: WHO; 1995.

18. World Health Organization (WHO). Measuring obesityclassification and description of anthropometric data. Report of a WHO Regional Office Consultation on the Epidemiology of Obesity. Copenhagen, Denmark: WHO Regional Office for Europe, Nutrition Unit. (Document EUR/ICP/NUT 125). Geneva: WHO; 1988.

19. Lukaski HC, Johnson PE, Bolonchuk WW, Lykken GI. Assement of fat-free mass using bioelectrical impedance measurement of the human body. Am J Clin Nutr. 1985;41:810-7.

20. Friedewald WT, Levy RI, Fredrickson DS. Estimation of the concentration of low-density lipoprotein cholesterol in plasma, without use of the preparative ultracentrifuge. Clin Chem. 1972;18:499-502.

21. World Health Organization (WHO). The world health report 1997 - conquering suffering, enriching humanity [citado 11 Ene 2010]. Disponible en: http://www.who.int/whr/1997/en/ index.html

22. Consenso Latino Americano de Obesidade. Arq Bras Endocrinol Metab. 1999;43:21-67.

23. Diretrizes Brasileiras de Obesidade. 3. ${ }^{\mathrm{a}}$ ed. Associação Brasileira para o Estudo da Obesidade e da Síndrome Metabólica (ABESO); 2009-2010.

24. Magro DO, Gelazone B, Delfini R, Pareja BC, Callejas F, Pareja JC. Long-term weight regain after gastric bypass: a 5-year prospective study. Obes Surg. 2008;18:648-51.

25. Dapri G, Cadière GB, Himpens J. Laparoscopic placement of non-adjustable silicone ring for weight regain after Roux-en-Y gastric bypass. Obes Surg. 2009;19:650-4. 
26. Faria SL, Kelly EO, Kins RD, Faria OP. Nutritional management of weight regain after bariatric surgery. Obes Surg. 2008;20: 135-9.

27. Ribeiro AG, Faintuch J, Dias MCG, Cecconello I. Euglycemia and normolipidemia after anti-obesity gastric bypass. Nutr Hosp. 2009;24:32-9.

28. Silva EN, Sanhes MD. Perfil lipídico de obesos antes e após a derivação gástrica a Fobi-Capella. Rev Col Bras Cir. 2006;33: 91-5.

29. American Dietetic Association (ADA). Position of the American Dietetic Association: health implications of dietary fiber. J Am Diet Assoc. 1993;93:1446-7.

30. Little TJ, Horowitz M, Feinle-Bisset C. Modulation by high-fat diets of gastrointestinal function and hormones associated with the regulation of energy intake: implications for the pathophysiology of obesity. Am J Clin Nutr. 2007;86: 531-41.
31. Essah PA, Levy JR, Sistrun SN, Kelly SM, Nestler JE. Effect of macronutrient composition on postprandial peptide YY levels. J Clin Endocrinol Metab. 2007;92:4052-5.

32. Sales RL, Costa NMB, Monteiro JBR, Peluzio MCG, Coelho SB, Oliveira CG, et al. Efeito dos óleos de amendoim, açafrão e oliva na composição corporal, metabolismo energético, perfil lipídico e ingestão alimentar de indivíduos eutróficos normolipidêmicos. Rev Nutr. 2005;8:499-511.

33. Flint A, Helt B, Raben A, Toubro S, Astrup A. Effects of different dietary fat types on posprandial appetite and energy expenditure. Obes Res. 2003;11:1449-55.

34. Smeets AJPG, Westerterp-Plantega MS. Satiety an substrate mobilization after oral fat stimulation. Br J Nutr. 2006;95:795-801.

35. Parra D, Ramel A, Bandarra N, Kiely M, Martínez A, Thorsdottir I. A diet rich in long chain omega- 3 fatty acids modulates satiety in overweight and obese volunteers during weight loss. Appetite. 2008;51:676-80. 